The

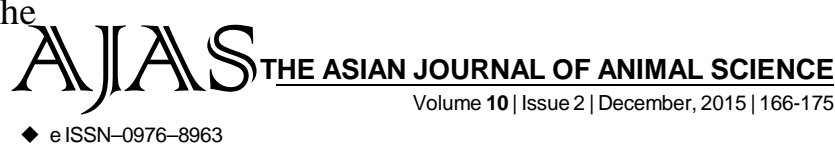

DOI : 10.15740/HAS/TAJAS/10.2/166-175

Visit us | www.researchjournal.co.in $\mathrm{S}$

RESEARCH ARTICLE.

\title{
Documentation of the technology used by milk sweet makers (Halwai) for preparation of indigenous milk products
}

V.S. KADAM, J.N. KHEDKAR, D.M. CHOUDHARI AND B.K. PAWAR

\begin{abstract}
V.S.
ABSTRACT...... The documentation data was collected from six district of Western Maharashtra (Jalgaon, Nasik, Ahmednagar, Pune, Satara and Kolhapur). Sixty respondents from each district were selected randomly. Disproportionate random sampling method was used to ensure a random selection of 60 milk sweet shop. Accordingly we found that, the Milk and milk product manufacture process technique and marketing system was found to be traditional, under- developed, fragmented and inefficient. Thus, for strengthening the status/ profile of Halwais, the government actions are required to license and inspect competing milk

Author for Corresponding -

sweet makers (Halwai) to ensure to achieve clean, hygienic and quality standards in order to facilitate the milk product processing and marketing.
\end{abstract}

V.S. KADAM

Department of Animal Science and Dairy Science, Post Graduate Institute, Mahatma Phule Krishi

Vidyapeeth, Rahuri, AHMEDNAGAR (M.S.) INDIA

See end of the article for

Coopted authors'
KEY WORDS...... Milk, Sweet, Product

HOW TO CITE THIS ARTICLE - Kadam, V.S., Khedkar, J.N., Choudhari, D.M. and Pawar, B.K. (2015). Documentation of the technology used by milk sweet makers (Halwai) for preparation of indigenous milk products. Asian J. Animal Sci., 10(2): 166-175.

ARTICLE CHRONICLE - Received : 10.08.2015; Revised : 13.11.2015; Accepted : 19.11.2015 